\title{
Mycoplasma synoviae induces upregulation of apoptotic genes, secretion of nitric oxide and appearance of an apoptotic phenotype in infected chicken chondrocytes
}

\author{
Daliborka Dusanic ${ }^{1 *}$, Dusan Bencina ${ }^{1}$, Irena Oven ${ }^{1}$, Ivanka Cizelj ${ }^{1}$, Mojca Bencina ${ }^{2}$ and Mojca Narat ${ }^{1}$
}

\begin{abstract}
The role of chondrocytes in the development of infectious arthritis is not well understood. Several examples of mycoplasma-induced arthritis in animals indicate that chondrocytes come into direct contact with bacteria. The objective of this study was to analyze the interaction of an arthrogenic Mycoplasma synoviae strain WVU 1853 with chicken chondrocytes. We found that $M$. synoviae significantly reduces chondrocyte respiration. This was accompanied by alterations in chondrocyte morphology, namely cell shrinkage and cytoplasm condensation, as well as nuclear condensation and formation of plasma membrane invaginations containing nuclear material, which appeared to cleave off the cell surface. In concordance with these apoptosis-like events in chondrocytes, transcription was increased in several pro-apoptotic genes. Twenty-four hours after infection, strong upregulation was assayed in NOS2, Mapk11, CASP8 and Casp3 genes. Twenty-four and $72 \mathrm{~h}$ incubation of chondrocytes with M. synoviae induced upregulation of AIFM1, NFKB1, htrA3 and BCL2. Casp3 and NOS2 remained upregulated, but upregulation ceased for Mapk11 and CASP8 genes. Increased production of nitric oxide was also confirmed in cell supernates. The data suggests that chicken chondrocytes infected with M. synoviae die by apoptosis involving production of nitric oxide, caspase 3 activation and mitochondrial inactivation. The results of this study show for the first time that mycoplasmas could cause chondrocyte apoptosis. This could contribute to tissue destruction and influence the development of arthritic conditions. Hence, the study gives new insights into the role of mycoplasma infection on chondrocyte biology and development of infectious arthritis in chickens and potentially in humans.
\end{abstract}

\section{Introduction}

Species from the genus Mycoplasma have long been recognized as important pathogens that cause diseases of the respiratory tract, urogenital tract and joints in a variety of animal species, including humans. Mycoplasma synoviae (M. synoviae) is a common pathogen of chickens and turkeys. It usually colonizes the respiratory tract, although this condition can lead to the development of systemic infection and/or infectious synovitis [1-4]. Experimental infectious synovitis has been associated with the hemagglutination-positive phenotype of M. synoviae [5]. The condition is presented as an acute

\footnotetext{
* Correspondence: Daliborka.Dusanic@bf.uni-lj.si

'University of Ljubljana, Department of Animal Science, Chair for Genetics, Animal Biotechnology and Immunology, Groblje 3, 1230 Domzale, Slovenia Full list of author information is available at the end of the article
}

\footnotetext{
.
}

joint swelling accompanied by increased volume of synovial fluid, infiltration with macrophages, $\mathrm{B}$ and $\mathrm{T}$ cells, lining cell hyperplasia and fibroblastic proliferation. In the acute phase of infection, live $M$. synoviae have been detected in synovial fluids of infected birds, suggesting that $M$. synoviae can come into direct contact with chondrocytes as is the case with M. pulmonis [6] and M. artritidis [7]. M. synoviae has been reported capable of invasion into non-phagocytic chicken cells including chondrocytes in vitro [8].

Mycoplasmas have been reported in many studies as active players in host-pathogen interactions leading to alterations in cell death patterns (Table 1) [9-22]. To our knowledge, there has been no report of any Mycoplasma species having apoptosis modulating effects on infected chondrocytes. Therefore, we conducted this

(C) 2012 Dusanic et al; licensee BioMed Central Ltd. This is an Open Access article distributed under the terms of the Creative Commons Attribution License (http://creativecommons.org/licenses/by/2.0), which permits unrestricted use, distribution, and reproduction in any medium, provided the original work is properly cited. 
Table 1 Mycoplasma species with reported roles in apoptosis modulation.

\begin{tabular}{|c|c|c|c|c|}
\hline $\begin{array}{l}\text { Mycoplasma } \\
\text { species }\end{array}$ & Host species & Disease(s) & Apoptosis modulation mechanism & Reference \\
\hline M. hyorhinis & swine & $\begin{array}{l}\text { Polyserositis, otitis media, } \\
\text { arthritis, pneumonia }\end{array}$ & $\begin{array}{l}\text { Induces apoptosis in human carcinoma cell line AZ-521 by } \\
\text { activation of NOS2 and caspase } 3 .\end{array}$ & [9] \\
\hline M. bovis & cattle & $\begin{array}{l}\text { Chronic unresponsive } \\
\text { pneumonia, systemic infection, } \\
\text { mastitis, arthritis }\end{array}$ & $\begin{array}{l}\text { Inhibits proliferation without apoptosis or effect on function of } \\
\text { lymphocytes and peripheral blood mononuclear cells. Induces } \\
\text { apoptosis of bovine lymphocytes. }\end{array}$ & {$[10,11]$} \\
\hline M. fermentans & humans, mice & $\begin{array}{l}\text { Possible role in arthritis (found } \\
\text { in patients) }\end{array}$ & $\begin{array}{l}\text { Reduces TNF-induced apoptosis upstream of caspase } 8 \text { in a } \\
\text { myelomonocitic cell line. Prevents apoptosis of } 32 D \text { cells by } \\
\text { inducing NF } \kappa B \text { gene upregulation. Promotes immortalization of } \\
\text { human peripheral blood mononuclear cells in culture. Promotes } \\
\text { proliferation of synovial fibroblasts. }\end{array}$ & {$[12-15]$} \\
\hline M. alligatoris & alligators & $\begin{array}{l}\text { Acute lethal cardiopulmonary } \\
\text { disease }\end{array}$ & $\begin{array}{l}\text { Promotes CD95 expression and apoptosis of primary cardiac } \\
\text { fibroblasts through modulation of CD44 receptor. }\end{array}$ & {$[16]$} \\
\hline M. hominis & humans & $\begin{array}{l}\text { Possible role in arthritis (found } \\
\text { in patients) }\end{array}$ & $\begin{array}{l}\text { Induces cell death in HeLa cells (through ATP release) and in 32D } \\
\text { cells. }\end{array}$ & {$[14,17]$} \\
\hline M. penetrans & humans & $\begin{array}{l}\text { Possible role in arthritis (found } \\
\text { in patients) }\end{array}$ & $\begin{array}{l}\text { Mediates NF } \kappa \text { B activation in mouse macrophages and induces } \\
\text { apoptosis. } \\
\text { Prevents apoptosis of } 32 \mathrm{D} \text { cells by inducing NF } \kappa \mathrm{B} \text {. }\end{array}$ & {$[14,18]$} \\
\hline M. arginini & $\begin{array}{l}\text { humans, rodents, } \\
\text { camels, sheep, } \\
\text { pigs }\end{array}$ & $\begin{array}{l}\text { Pneumonia, chronic respiratory } \\
\text { disease, otitis }\end{array}$ & $\begin{array}{l}\text { Inhibits apoptosis of cells expressing toll-like receptors } 2 / 6 \text { by } \\
\text { inducing constitutive NFkB activation and p53 suppression. } \\
\text { Suppression of tp } 53 \text { gene induces carcinogenic and mutagenic } \\
\text { effects on rodent fibroblasts. }\end{array}$ & {$[19,20]$} \\
\hline M. genitalium & humans & $\begin{array}{l}\text { Urethritis, pelvic inflammatory } \\
\text { disease, pneumonia, arthritis }\end{array}$ & $\begin{array}{l}\text { Does not affect 32D cells. Induces apoptosis in human monocytes } \\
\text { THP-1 by activating NF } \kappa \text { B. }\end{array}$ & {$[14,21]$} \\
\hline $\begin{array}{l}\text { M. } \\
\text { pneumoniae }\end{array}$ & humans & $\begin{array}{l}\text { Atypical pneumonia, possible } \\
\text { role in arthritis }\end{array}$ & Supports continous growth of 32D cells. & {$[22]$} \\
\hline
\end{tabular}

study to elucidate the impact of Mycoplasma synoviae infection on chicken chondrocytes.

Apoptosis is a highly regulated process of cell demise and is generally induced through activation of different components of two overlapping signaling pathways. The extrinsic pathway includes the activation of death receptors leading to activation of a family of cysteine proteases known as caspases [23]. Proteolytic cleavage of around 400 caspase substrates that have been identified so far [24] leads to phenotypic features of apoptosis. These include rounded morphology, condensed cytoplasm, fragmented organelles and formation of plasma membrane blebs that are separated from the cell into independent vesicles known as apoptotic bodies (reviewed in [25]). The intrinsic pathway is linked to stress signals from within the cell. It involves cleavage of Bid into tBid leading to activation of Bax and Bak1. They form a pore in the outer mitochondrial membrane and cause the release of proteins from the mitochondrial intermembrane space (endonuclease G, AIFM1, cytochrome c etc.) leading to execution of either caspase independent DNA cleavage (AIFM1, endonuclease G) [26] or the formation of apoptosome and activation of caspase $3[27,28]$.

One of the key players in the induction of apoptosis of articular chondrocytes in humans is nitric oxide (NO), which is produced by immune cells in the synovium and pannus as well as by activated chondrocytes [29-32]. NO induces apoptosis through p38 MAP kinase (MAPK11) mediated stimulation of caspase 3 activity and accumulation of nuclear factor $\mathrm{kB}(\mathrm{NFkB})$. This leads to increased expression of p53, a signaling molecule that acts upstream of caspase $3[33,34]$, as well as upregulation of pro-apoptotic Bax. Another mechanism of apoptosis in arthritic cartilage includes activation of CD95 (Fas) death receptor leading to upregulation of Fas ligand and p38 MAP kinase [35].

In this study, M. synoviae infected chicken chondrocytes $(\mathrm{CCH})$ were evaluated during three days for changes in cell viability, morphology and expression of genes associated with apoptosis.

\section{Materials and methods}

\section{$\mathrm{CCH}$ cell culture}

Chicken chondrocytes $(\mathrm{CCH})$ were obtained from hyaline cartilage of hock joints as described previously [8]. Primary cultures of $\mathrm{CCH}$ were cultivated up to the sixth passage in Dulbecco Modified Eagles Medium (DMEM), supplemented with $7.5 \%$ fetal bovine serum (FBS) and $2.5 \%$ chicken serum (all from Sigma-Aldrich, Munich, Germany). Cells were incubated at $37^{\circ} \mathrm{C}$ in a $5 \% \mathrm{CO}_{2}$ incubator.

\section{Jurkat cell culture}

Jurkat cells (ATCC, CCL TIB 152, kindly donated by Prof Nataša Kopitar Jerala, Jožef Stefan Institute, 
Slovenia) that overexpress death receptors were used as a positive control for apoptosis. Cells were cultivated in DMEM supplemented with 10\% FBS and incubated at $37^{\circ} \mathrm{C}$ in a $5 \% \mathrm{CO}_{2}$ incubator.

\section{Mycoplasma synoviae cultures}

Cultures of M. synoviae type strain WVU 1853 (approximately 20 in vitro passages before being used in this study) were grown in Frey mycoplasma broth as described previously [8]. Bacteria in the logarithmic phase of growth were used for $\mathrm{CCH}$ infection. The number of colony forming units (CFU) was determined as described previously [36].

\section{XTT-based cell viability test}

To perform the cell viability test, $\mathrm{CCH}$ were seeded into 96 well plates (Corning, New York, USA) at density $5 \times$ $10^{5}$ cells $/ \mathrm{mL}$ and incubated overnight at $37^{\circ} \mathrm{C}$ in a $5 \%$ $\mathrm{CO}_{2}$ incubator prior to infection. $M$. synoviae broth culture in the logarithmic phase of growth was used to infect $\mathrm{CCH}$ in a ratio of 10-100 M. synoviae CFU per $\mathrm{CCH}$. As a positive control of apoptosis, 5-fluorouracil was used (5-FU, final concentration $20 \mu \mathrm{g} / \mathrm{mL}$, from Sigma-Aldrich, Munich, Germany). Non-infected $\mathrm{CCH}$ were used as negative controls. As additional controls of the experiment, Jurkat cells, seeded at density $5 \times 10^{5} /$ well, were subjected to the same three procedures. Tetrazolium-based dye XTT (Sigma-Aldrich, Munich, Germany) was added to wells after $0,24,48,72$ and $96 \mathrm{~h}$ of incubation. The final concentration of XTT in cell suspensions was $20 \%$. Following $3 \mathrm{~h}$ of incubation at $37^{\circ} \mathrm{C}$ in a $5 \% \mathrm{CO}_{2}$ incubator, absorbance of the samples was measured at $492 \mathrm{~nm}$. The background signal was measured at $690 \mathrm{~nm}$. The test was performed in three independent experiments with triplicates of each experimental condition. Average absorbances were calculated using MS Excel. Student $t$-test for independent values was used for determining statistically significant differences $(p<0.05)$.

\section{Phase contrast and confocal fluorescence microscopy}

Morphological changes were observed by phase contrast and confocal fluorescence microscopy. $\mathrm{CCH}$ were seeded onto cover slides at density $5 \times 10^{5}$ cells $/ \mathrm{mL}$ and incubated overnight. The cells were then infected with M. synoviae as described and incubated for $24 \mathrm{~h}, 48 \mathrm{~h}$ and $72 \mathrm{~h}$ followed by phase contrast microscopy examinations for morphological changes. Additionally, distribution of CD44 receptor (hyaluronan receptor; its crosslinking augments Fas expression and subsequent Fasmediated apoptosis of the cells [37]), and nuclear condensation were observed using confocal fluorescence microscopy. The medium was aspirated, and $\mathrm{CCH}$ were washed in sterile phosphate buffered saline (PBS). The cells were fixed using a pre-cooled mixture of acetone and methanol (both from Sigma-Aldrich, Munich, Germany) for $10 \mathrm{~min}$ at room temperature. A solution of $10 \%$ goat serum (Sigma-Aldrich, Munich, Germany) was used for blocking ( $1 \mathrm{~h}$, room temperature), followed by 3 washes in PBS containing $0.5 \mathrm{mg} / \mathrm{mL}$ RNase (SigmaAldrich, Munich, Germany). Mouse monoclonal antibodies to chicken CD44 (DSHB, Iowa City, USA), diluted 1:100 in PBS were added for $1 \mathrm{~h}$ at room temperature. After washing, Alexafluor-488 goat anti-mouse IgG antibodies, diluted 1:2000 (Life Technologies - Invitrogen, Carlsbad, USA), were used as secondary antibodies. After $1 \mathrm{~h}$ at $37^{\circ} \mathrm{C}$, unbound antibodies were washed off, and nuclei were labeled for $5 \mathrm{~min}$ in propidium iodide (Sigma-Aldrich, Munich, Germany) in PBS with 0.1\% Triton X-100 and $0.5 \mathrm{mg} / \mathrm{mL}$ RNase (both from SigmaAldrich, Munich, Germany). Following washing in PBS, cover slides were mounted using Dako Fluorescence Mounting medium (Dako, Glostrup, Denmark) and viewed using a Leica TCS SP5 confocal microscope (Leica Microsystems, Mannheim, Germany).

\section{RT-qPCR}

In order to perform gene expression analysis, $\mathrm{CCH}$ were seeded into $75 \mathrm{~cm}^{2}$ flasks (Techno Plastic Products, St. Louis, USA) at density $5 \times 10^{5}$ cells $/ 10 \mathrm{~mL}$ and incubated overnight. The cells were then treated as described for the XTT assay and sampled by trypsinization after 24,48 and $72 \mathrm{~h}$ of incubation. $\mathrm{CCH}$ were washed in sterile PBS followed by isolation of total RNA using RNeasy Mini Kit (Qiagen GmbH, Hilden, Germany). RNA concentration was determined spectrophotometrically using NanoVue (GE Healthcare, Waukesha, USA). Subsequently, RNA was stored at $-80^{\circ} \mathrm{C}$. Residual DNA was eliminated by incubating $1 \mu \mathrm{g}$ of RNA with $1 \mathrm{U}$ of RNase-free DNase I in a buffer containing $\mathrm{MgCl}_{2}$ ions (both from Thermo Fisher Scientific - Fermentas, St. Leon-Rot, Germany) for $30 \mathrm{~min}$ at $37^{\circ} \mathrm{C}$. Following DNase inactivation at $65^{\circ} \mathrm{C}, \mathrm{cDNA}$ was synthesized using a High-Capacity cDNA Reverse Transcription Kit (Life Technologies - Applied Biosystems, Foster City, USA), according to the manufacturer's instructions. cDNA was stored at $-20^{\circ} \mathrm{C}$ immediately after reverse transcription reactions. Prior to use, primer pairs were checked for specificity in silico using NCBI Primer BLAST [38]. Primer efficiency was checked on each primer pair using dilutions of cDNA combined from all experimental conditions and timepoints.

For RT-qPCR reactions, $20 \mu \mathrm{L}$ mixtures were made, containing $10 \mu \mathrm{L}$ of Power SYBR Green PCR Master Mix (Life Technologies - Applied Biosystems, Foster City, USA), $0.5 \mu \mathrm{L}$ of forward and $0.5 \mu \mathrm{L}$ of reverse primer (final concentration $5 \mu \mathrm{M}$, Integrated DNA Technologies, Leuven, Belgium), $8 \mu \mathrm{L}$ of DEPC-treated water 
(Qiagen GmbH, Hilden, Germany) and $1 \mu \mathrm{L}$ of cDNA. Stratagene Mx3000P (Agilent Technologies - Stratagene, Santa Clara, USA) was used to perform RT-qPCR reactions and its MxPro software for analysis of amplification and dissociation plots. Reaction conditions were set to $10 \mathrm{~min}$ at $95^{\circ} \mathrm{C}$ (first segment, one cycle), $15 \mathrm{~s}$ at $95^{\circ}$ $\mathrm{C}$ and $1 \mathrm{~min}$ at $\mathrm{Tm}$ of a specific primer pair (second segment, 40 cycles) followed by one cycle with $15 \mathrm{~s}$ at $95^{\circ} \mathrm{C}, 30 \mathrm{~s}$ at $\mathrm{Tm}$ and $15 \mathrm{~s}$ at $95^{\circ} \mathrm{C}$ (dissociation curve segment). Gene expression was analyzed for 15 genes (Table 2, [39]), and GAPDH was used as a reference gene [40]. Gene expression values of non-infected $\mathrm{CCH}$ were used for gene expression calibration. Appropriate controls (no template and no reverse transcription control) were also performed in each run.

Three independent experiments were performed to collect RNA for RT-qPCR. Relative gene expression was assayed in each experiment and experimental condition separately. Three repeats of each $\mathrm{RT}$-qPCR reaction were performed. Normalized relative quantities were calculated using the efficiency corrected $2^{-\Delta \Delta C q}$ method [41]. The effect of intra-assay variation on the statistical significance of the results was reduced by log transformation of normalized relative quantities, mean centering and autoscaling as described in [42]. Statistical significance of the results was determined using the Student $t$ test $(p<0.05)$ and statistically significant results visualized through Ingenuity Pathways Analysis platform (Ingenuity Systems, Redwood City, USA).

\section{Nitric oxide assay}

In order to determine the concentration of $\mathrm{NO}$, an experiment equal to XTT-based cell proliferation test was set up using $\mathrm{CCH}$. After 24, 48 and $72 \mathrm{~h}$ of incubation, supernates were transferred to a sterile 96-well plate and assayed immediately using the Griess assay (R\&D Systems, Minneapolis, USA). The concentration of $\mathrm{NO}$ was determined based on the standard curve and absorbances of the azo-compound NO forms in the reaction with sulfanilamide and N-1-naftyletylendiamin dihydrochloride. Absorbances were read at $550 \mathrm{~nm}$ (background at $630 \mathrm{~nm}$ ). Two independent experiments with three replicates of each condition were performed and mean absorbances \pm standard errors were used to test statistical significance of the results (Student $t$-test, $p<0.05)$.

\section{Results}

\section{M. synoviae decreased $\mathrm{CCH}$ and Jurkat cell respiration} (viability)

We assayed the respiration of $\mathrm{CCH}$ by determining the relative decrease in reduction of tetrazolium salt XTT in M. synoviae infected $\mathrm{CCH}$ compared to the negative control. As a positive control, $\mathrm{CCH}$ were treated with 5-
FU. Jurkat cells were used as an additional positive control. M. synoviae infection caused significant decrease in $\mathrm{CCH}$ respiration, indicating reduced viability. This effect was noticed $72 \mathrm{~h}$ and $96 \mathrm{~h}$ after infection $(p \leq 0.1)$ (Figure 1). An even stronger decrease in respiration, already after $24 \mathrm{~h}$, was noticed in $\mathrm{CCH}$ treated with 5-FU (Figure 1). Jurkat cells responded stronger than $\mathrm{CCH}$ to both treatments, with a major decrease in cell respiration apparent already after $24 \mathrm{~h}$ in both cases $(p<0.01)$ (Figure 1). Fresh medium was not added to any of the cells at the time of measurements, resulting in a decrease in viability of fast-growing Jurkat cells even in negative controls after $96 \mathrm{~h}$ (Figure 1).

\section{M. synoviae infected $\mathrm{CCH}$ exhibited apoptotic morphology and nuclear condensation}

Phase contrast microscopy of infected $\mathrm{CCH}$ revealed dramatic changes in cell morphology (Figure 2). Twenty-four hours after infection with $M$. synoviae, some $\mathrm{CCH}$ were shrinking. Plasma membranes appear rough but formation of membrane vesicles was not noticed. The cytoplasm of infected cells shows increased vacuolization. However, the number of cells that adhered to cover slides was roughly comparable to the control (Figure 2). Longer exposure to $M$. synoviae resulted in more pronounced vacuolization of cytoplasm and formation of membrane blebs seen $48 \mathrm{~h}$ after infection (Figure 2). After $72 \mathrm{~h}$, cytoplasm vacuolization was present in some of the uninfected $\mathrm{CCH}$, to which no fresh medium was added after seeding into plates. Still, most cells were attached to cover slides. In contrast, only a few cells infected with $M$. synoviae remained attached to cover slides (Figure 2). The remaining ones exhibited excessive membrane blebbing with individual vesicles detaching from cells or cytoplasm condensation (cell shrinkage) and/or vacuolization (Figure 2). In $\mathrm{CCH}$ treated with 5-FU, membrane roughness and cell shrinkage was noticed after $24 \mathrm{~h}$, but with no cytoplasm vacuolization present. A similar morphology was observed $48 \mathrm{~h}$ after treatment, but in a larger number of cells. The number of cells still attached to the surface was lower than in the control slide and some cells presented with membrane blebs. Seventy-two hours of treatment with 5-FU caused cell death and detachment from cover slides in most cells, with remaining cells presenting similar morphological features as those infected with $M$. synoviae (Figure 2).

Confocal microscopy of infected $\mathrm{CCH}$ labeled with antibodies to membrane receptor CD44 and propidium iodide revealed additional changes caused by $M$. synoviae infection (Figure 3). The nuclei of negative controls stained evenly with PI after all three timepoints, while brighter foci indicating condensed DNA were present in $\mathrm{CCH}$ infected with $M$. synoviae. Additionally, vesicles 
Table 2 A list of oligonucleotides used as primers in RT-qPCR analysis of gene expression in chicken chondrocytes.

\begin{tabular}{|c|c|c|c|c|c|c|}
\hline $\begin{array}{l}\text { Gene } \\
\text { symbol }\end{array}$ & $\begin{array}{l}\text { RefSeq mRNA } \\
\text { number }\end{array}$ & Forward primers & Reverse primers & $\begin{array}{l}\text { Amplicon } \\
\text { lenght }\end{array}$ & Reference & Encoded protein function \\
\hline Casp3 & NM_204725.1 & TGGCCCTCTTGAACTGAAAG & TCCACTGTCTGCTTCAATACC & 139 & $\mathrm{IDT}^{1}$ & $\begin{array}{l}\text { Caspase 3: apoptosis related } \\
\text { cysteine peptidase from the } \\
\text { group of effector caspases. }\end{array}$ \\
\hline$\overline{B a k 1}$ & NM_001030920.1 & GCCCTGCTGGGTTTCGGTAA & AATTCGGTGACGTAGCGGGC & 95 & $\mathrm{NCB|^{2 }}$ & $\begin{array}{l}\text { Bcl2 antagonist/killer: pro- } \\
\text { apoptotic member of the } \\
\text { Bcl2 family, involved in } \\
\text { mitochondrial pore formation. }\end{array}$ \\
\hline Fas & XM_421659.2 & CCTGCTCCTCATCATTGTGT & TGATCCATGTACTCCTCTCC & 258 & {$[20]$} & $\begin{array}{l}\text { Fas: TNF receptor superfamily, } \\
\text { member } 6 \text {. }\end{array}$ \\
\hline$\overline{F A S L G}$ & NM_001031559.1 & GGAGAAGGAACTGGCTGAAC & GGTTTCCTGTTAAGTGTGCTG & 134 & $\mathrm{IDT}^{1}$ & $\begin{array}{l}\text { Fas ligand: TNF superfamily, } \\
\text { member } 6 .\end{array}$ \\
\hline tp53 & NM_205264.1 & ACCTGCACTTACTCCCCGGT & TCTTATAGACGGCCACGGCG & 127 & $\mathrm{NCB|^{2 }}$ & $\begin{array}{l}\text { Tumor protein p53: tumor } \\
\text { suppressor, activator of } \\
\text { apoptosis through induction } \\
\text { of BAX expression. }\end{array}$ \\
\hline
\end{tabular}

AIFM1 NM_001007490.1 GAAGTACAACAACGGCTGAC $\quad$ GAGACAGAGACAGACTTGAC $299 \quad$ IDT $^{1} \quad$ Apoptosis-inducing factor:
pro-apoptotic mitochondrial protein, responsible for caspase-independent DNA cleavage.

\begin{tabular}{llllll}
\hline CASP8 NM_204592.2 & GGACAGGACTGAGCTGGCGT & AGGTCCCCCACCTCGATCATC 135 & NCBI $^{2}$ & $\begin{array}{l}\text { Caspase 8: apoptosis related } \\
\text { cysteine peptidase from the } \\
\text { group of initiator caspases. }\end{array}$ \\
\hline
\end{tabular}

\begin{tabular}{llllll}
\hline BCL2 NM_205339 & GATGACCGAGTACCTGAACC & CAGGAGAAATCGAACAAAGGC 114 & IDT $^{1}$ & B-cell CLL/lymphoma 2:
\end{tabular}
anti-apoptotic member of the Bcl2 family, blocks mitochondrial pore formation.

\begin{tabular}{llllll}
\hline endog & XM_415487.2 & GAACAACGTGGCCGTCCCT & GGGCATCACATAGGAGCGCA & 91 & NCBI $^{2}$
\end{tabular}

\section{Endonuclease G:}

mitochondrial endonuclease, released from mitochondria during apoptosis.

\begin{tabular}{|c|c|c|c|c|c|c|}
\hline$\overline{X I A P}$ & NM_204588.1 & GCAGAATATGAGAGGCGGATAC & TCCTTCCACTCTTGCAATCC & 149 & $\mathrm{IDT}^{1}$ & $\begin{array}{l}\text { X-linked inhibitor of } \\
\text { apoptosis: anti-apoptotic } \\
\text { protein from the IAP family, } \\
\text { blocks caspase } 3 \text { activation by } \\
\text { inhibiting caspase } 9 \text {. }\end{array}$ \\
\hline NOS2 & NM_204961.1 & GCATTCTTATTGGCCCAGGA & CATAGAGACGCTGCTGCCAG & 66 & $\mathrm{IDT}^{1}$ & $\begin{array}{l}\text { Nitric oxide synthase } \mathbf{2 ,} \\
\text { inducible: pleiotropic } \\
\text { immune system regulator, } \\
\text { inducer of apoptosis in } \\
\text { chondrocytes. }\end{array}$ \\
\hline$\overline{N F \kappa B 1}$ & NM_205134.1 & AGGACTTAAAATGGCAGGAGAG & GCTGTTCGTAGTGGTAAGTCTG & 141 & $\mathrm{IDT}^{1}$ & $\begin{array}{l}\text { Nuclear factor of kappa } \\
\text { light polypeptide gene } \\
\text { enhancer in B-cells } 1 \text { : } \\
\text { transcription factor with pro- } \\
\text { or anti-apoptotic functions. }\end{array}$ \\
\hline CD44 & NM_204860.2 & AGCACTGGTCTITACTGGAAC & TCTGAGCAACTTGGGAAACTG & 93 & $\mathrm{IDT}^{1}$ & $\begin{array}{l}\text { CD44 molecule (Indian } \\
\text { blood group): hyaluronan } \\
\text { receptor, involved in } \\
\text { interaction of the cell with } \\
\text { the extracellular matrix, } \\
\text { capable of inducing caspase- } \\
\text { independent death via } \\
\text { calpain-dependent AIF } \\
\text { release. Crosslinking of CD44 } \\
\text { augments Fas expression and } \\
\text { mRNA transcription. }\end{array}$ \\
\hline
\end{tabular}

\begin{tabular}{lllllll}
\hline htrA3 XM_420813.2 CCTCCCGGGCTTCGTATTC & TGCAGTCGCGGTGCAGTAAG & 116 & NCBI & HtrA serine peptidase 3:
\end{tabular}


Table 2 A list of oligonucleotides used as primers in RT-qPCR analysis of gene expression in chicken chondrocytes. (Continued)

\begin{tabular}{|c|c|c|c|c|c|c|}
\hline $\begin{array}{l}\text { Mapk11 } \\
\text { (p38B) }\end{array}$ & NM_001006227.1 & GCGGCTCCGCTAAAATGCCG & GGGGTGAGGTTCTGGTAGCGC & 97 & $\overline{\left.N C B\right|^{2}}$ & $\begin{array}{l}\text { Mitogen-activated protein } \\
\text { kinase } 11 \text { : stimulates caspase } \\
3 \text { activity, NF } \kappa B \text { expression } \\
\text { and p53 expression and } \\
\text { protein stability. }\end{array}$ \\
\hline$\overline{G A P D H}$ & NM_204305.1 & ATGGCATCCAAGGAGTGAGC & AACAAAGGGTCCTGCTTCCC & 66 & [39] & $\begin{array}{l}\text { Glyceraldehide-3- } \\
\text { phosphate dehydrogenase: } \\
\text { enzyme in carbohydrate } \\
\text { metabolism. }\end{array}$ \\
\hline
\end{tabular}

${ }^{1}$ Designed in Integrated DNA Technologies PrimerQuest ${ }^{S M}$ application ${ }^{2}$ Designed in NCBI Primer-BLAST application

detaching from the blebbing $\mathrm{CCH}$ plasma membrane contained condensed DNA. Differences in CD44 receptor abundance and distribution were not obvious in $\mathrm{CCH}$ infected with $M$. synoviae. $\mathrm{CCH}$ treated with 5-FU appeared to express more CD44 (Figure 3).

M. synoviae induced upregulation of pro-apoptotic genes Expression of 15 genes (Table 2) was assayed in $\mathrm{CCH}$ exposed to 5-FU or infected with $M$. synoviae. The level of expression was normalized to untreated control cells and calibrated with reference to GAPDH expression. Upregulation of several genes was already observed in the cells sampled $24 \mathrm{~h}$ after infection. The gene encoding inducible nitric oxide synthase (NOS2) was upregulated 46-fold ( $p<0.001)$, Casp3 was upregulated 2.6fold $(p<0.001)$, Mapk11 3.2-fold $(p<0.01)$ and CASP8 2.9 -fold $(p<0.01)$ (Figure 4$)$. In $\mathrm{CCH}$ infected with $M$. synoviae for $48 \mathrm{~h}$, Casp3, NOS2 and Mapk11 remained upregulated (2.8-fold, 20.1-fold and 3.1-fold, respectively, $p<0.001$ ), while another gene, $h \operatorname{tr} A 3$, became slightly upregulated (1.6-fold, $p<0.01$ ) (Figure 4). Seventy-two

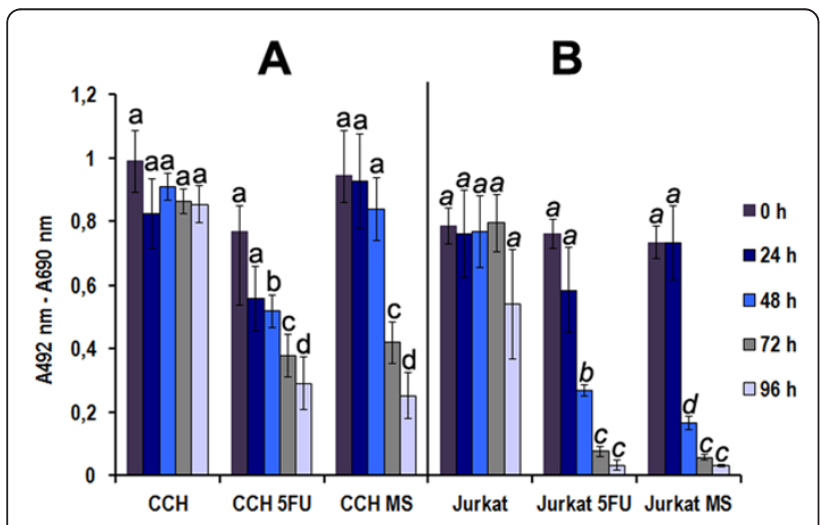

Figure 1 Cell respiration (viability) of control cells, cells treated with 5-fluorouracil (5-FU) or infected with $M$. synoviae. CCH or Jurkat cells were treated for indicated time periods and assayed using the XTT-based cell viability test. The results are presented as mean values \pm standard error for three independent experiments with three replicates each. Means with a different letter are different $(p<0.05$ to $p<0.001)$ by the Student $t$-test. hours after infection, Casp3 and NOS2 remained upregulated (4.4-fold and 7.7-fold, respectively, $p<0.001$ ), while Mapk11 was no longer upregulated. A strong increase in transcription was noticed in genes AIFM1 (6.7-fold, $p<0.001), N F \kappa B 1$ (2.5-fold, $p<0.001)$ and htrA3 (2.7-fold, $p<0.001)$. BCL2 was also upregulated (2-fold, $p<0.001$ ) (Figure 4$)$. No change in gene expression at all tested timepoints was noticed for $B a k 1$, endog, tp53, CD44, XIAP, Fas and FASLG (Additional file 1, Figure S1).

$\mathrm{CCH}$ treated with 5-FU revealed a pattern of gene expression that differed considerably from that of $\mathrm{CCH}$ infected with M. synoviae. As indicated by the XTT test and morphological changes, the effect of 5-FU was more pronounced compared to M. synoviae, especially 24 and $48 \mathrm{~h}$ after treatment. After $24 \mathrm{~h}$, strong upregulation was noticed in CD44 (11.3-fold, $p<0.001)$, AIFM1 (369.2-fold, 0.001), Fas (11.9-fold, $p<0.001)$, FASLG (4.3-fold, $p<0.05)$, NOS2 (3.1-fold, $p<0.01$ ), and $N F \kappa B 1$ (2.4-fold, $p<0.01)$. Interestingly, the expression of XIAP was also elevated after $24 \mathrm{~h}$ (3.6-fold, $p<0.01$ ). Increasing the incubation time to $48 \mathrm{~h}$ revealed a normalization of NF $\kappa B 1$, XIAP, AIFM1 and NOS2 expression together with upregulation of $t p 53$ (1.8-fold, $p<$ 0.05 ) and lower level of upregulation in CD44, Fas and FASLG (Figure 4). Seventy-two hours of incubation of $\mathrm{CCH}$ with 5-FU-supplemented medium left little living cells, in concordance with the results of the proliferation test and morphological observations, and these had only a few upregulated genes, including Fas (1.5-fold, $p<$ 0.05), Bak1 (1.3-fold, $p<0.05)$, CASP8 (1.8-fold, $p<$ 0.001 ) and Mapk11 (1.6-fold, $p<0.01$ ) (Figure 4, Additional file 1, Figure S1).

Interactions between proteins encoded by genes of interest, as well as levels of gene upregulation, were depicted using the Ingenuity Pathways platform (Figure 5).

\section{Chondrocytes infected with $M$. synoviae produced nitric oxide}

Infection of $\mathrm{CCH}$ with $M$. synoviae induced a significant increase in NO production at all tested time points ( $p \leq$ 0.01 ) (Figure 6), in agreement with the strong upregulation 


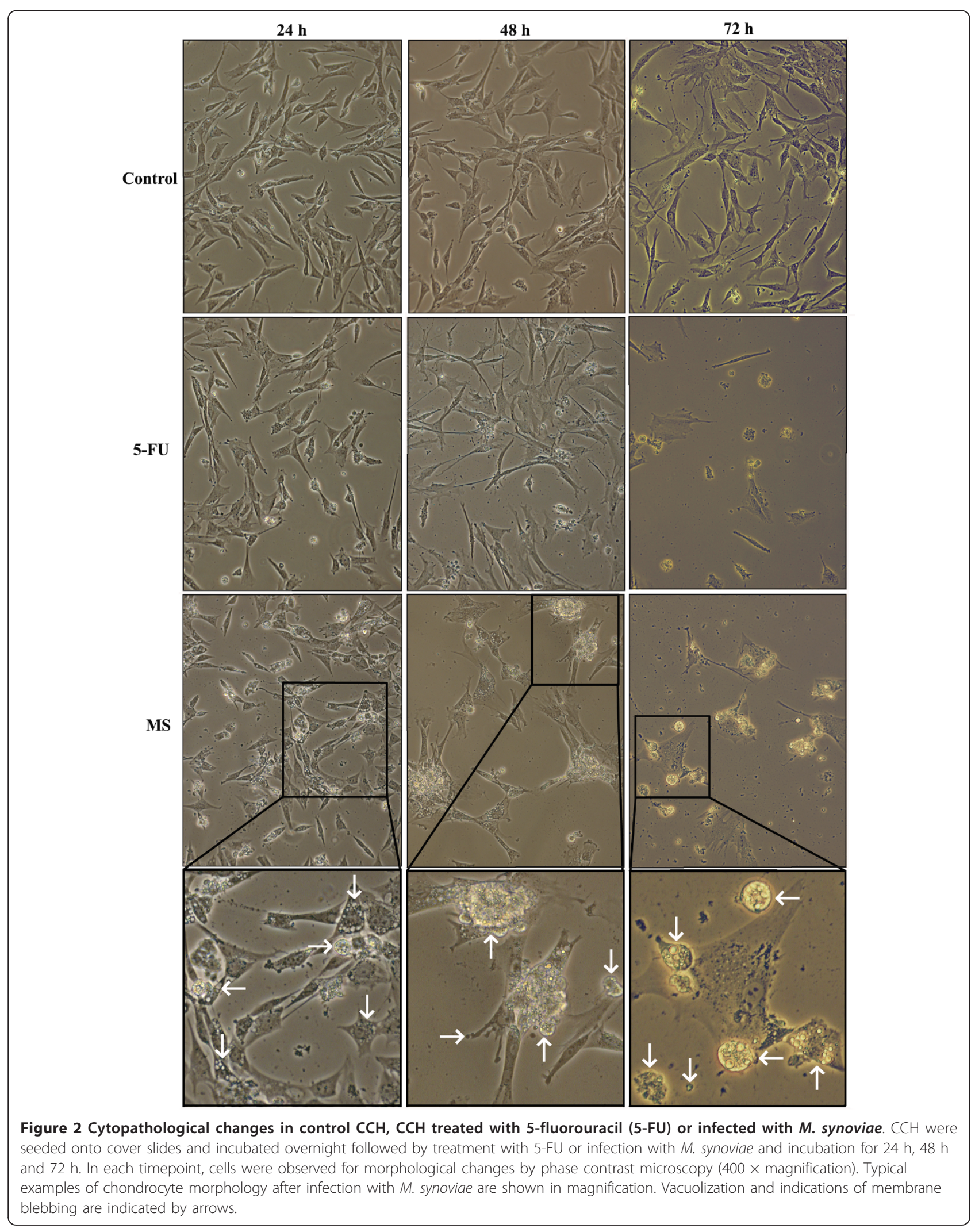




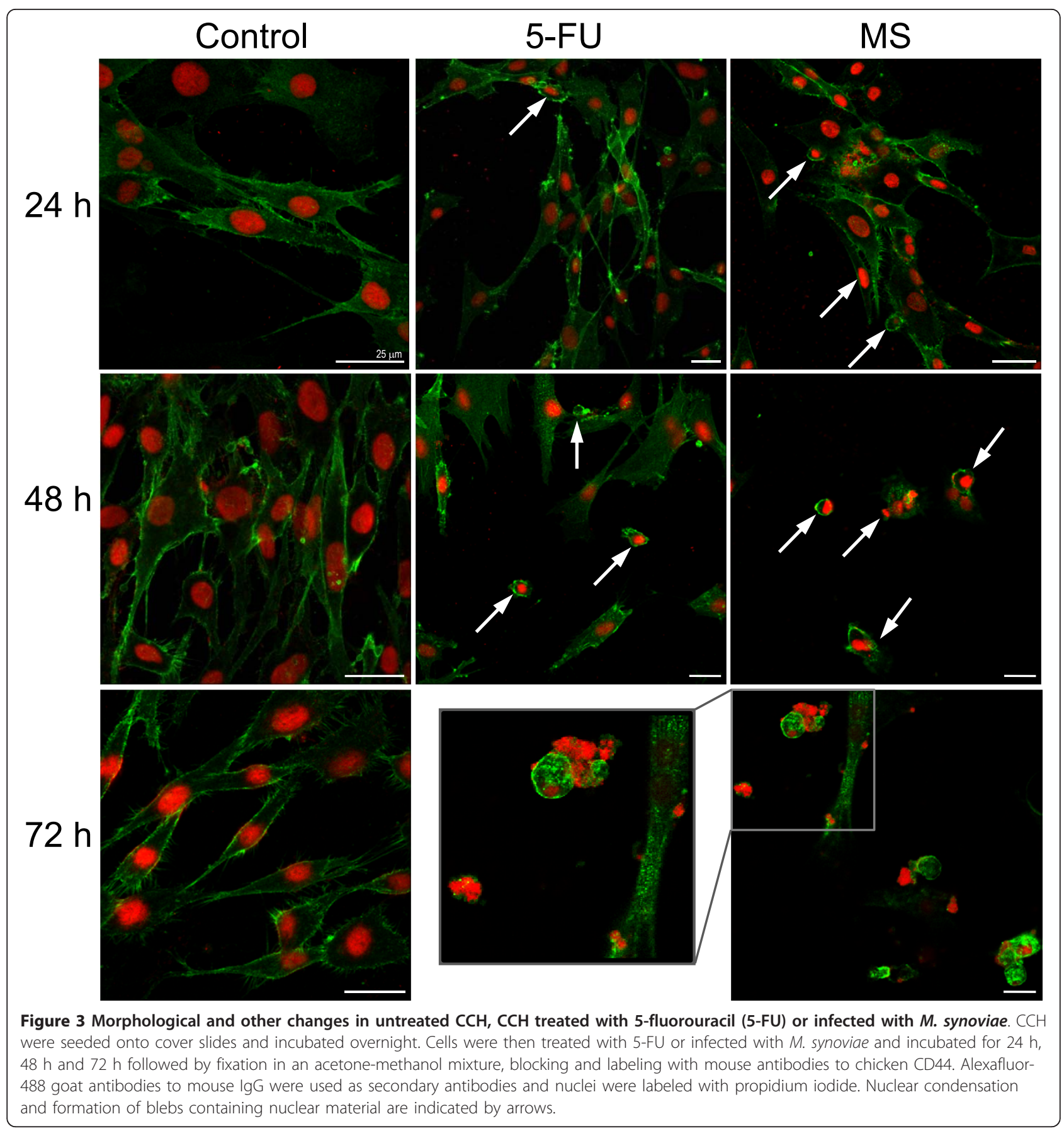

of NOS2. NO concentration doubled already 24 h after infection. During the next $48 \mathrm{~h}$, the concentration of NO did not increase significantly compared to the concentrations assayed after $24 \mathrm{~h}$.

\section{Discussion}

In the research of rheumatoid arthritis etiology, the idea of a bacterial infection leading to arthritis is becoming increasingly popular [43-45]. Bacterial infections increase the production of $\mathrm{NO}$, and can lead to inflammation. Inflammation then leads to chondrocyte apoptosis [30-35]. In cartilage tissue that is rich in extracellular matrix and with few cells in hard to reach places, clearance of dying cells is especially troublesome and can lead to the development and perpetuation of inflammation, which in turn leads to cartilage and bone degradation [46-48]. The idea of mycoplasmal infections, as the triggering factor of rheumatoid arthritis, has been 


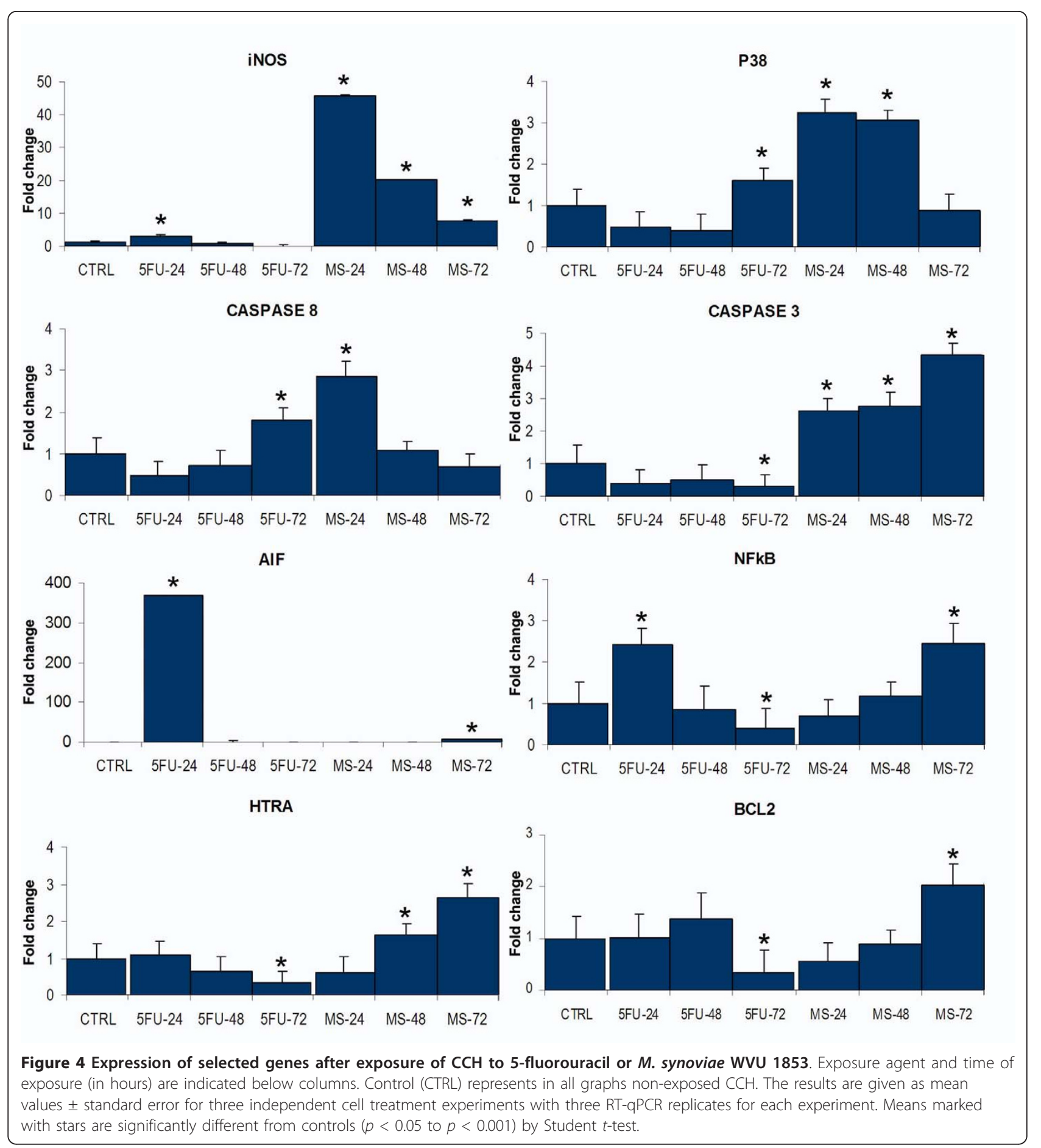

revisited several times. Still, the role of mycoplasmas that have been detected in synovial fluids and serums of patients suffering from arthropathies remains unclear [49-54]. Factors impeding these studies are many. Because of their obligatory parasitism and complex nutritional demands, mycoplasmas are hard to cultivate. In addition, mycoplasmas adapt to the host in a way that induces subclinical infections that pass with little or no inflammation. Furthermore, mycoplasmal antigens, many of which are enzymes, can affect cells even after bacteria are dead and lysed, and their presence is difficult to detect by certain conventional methods [49]. Mycoplasma species are also well known to cause arthritis in certain animal species, including chickens [1-7]. 


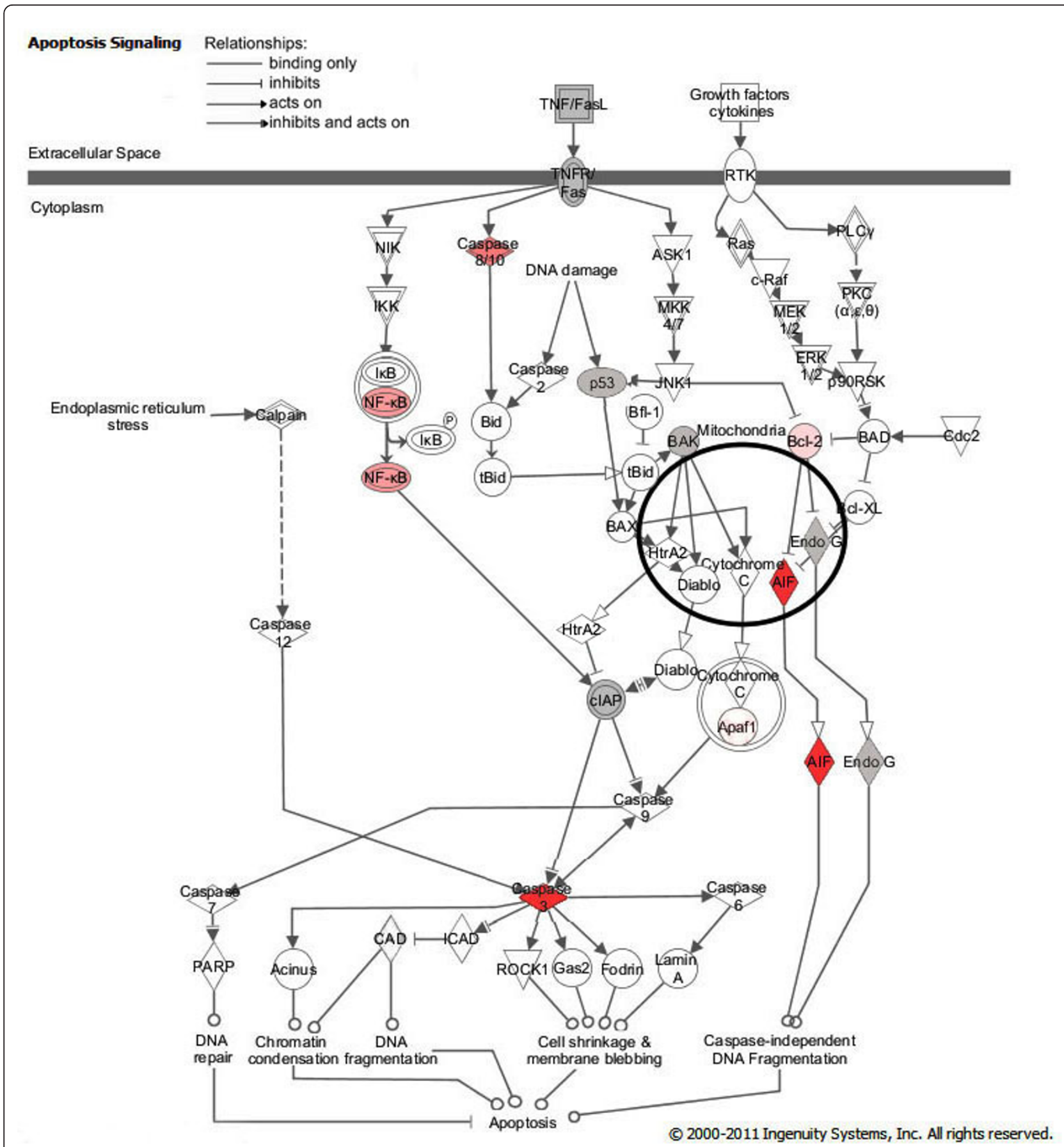

Figure 5 Ingenuity Pathway Analysis network depicting interactions between genes known to be involved in apoptosis induction. Two major pathways are shown, the death receptor (extrinsic) pathway, and mitochondria-dependent (intrinsic) pathway. Pink color of molecules indicates upregulation of genes analyzed in this study (level of upregulation after 24,48 or $72 \mathrm{~h}$ of CCH exposure to M. synoviae), with darker shades of pink representing higher levels of gene upregulation. Grey color indicates no change in gene expression, whereas molecules that were not analyzed are white. Types of relationships are explained in the legend. The pathways depicted represent conserved pathways generated from knowledge published for different species. (Note that exceptions specific for avian species could be possible).

Experimental infections of chickens with $M$. synoviae WVU 1853 resulted in thinning of the articular cartilage 25 days post infection [55]. Visible cartilage erosion appeared about two weeks later, presumably due to the presence of increasing numbers of heterophils. It seems likely that M. synoviae could also affect $\mathrm{CCH}$. This assumption is supported by our observations that synovial fluids of chickens infected experimentally into hock 


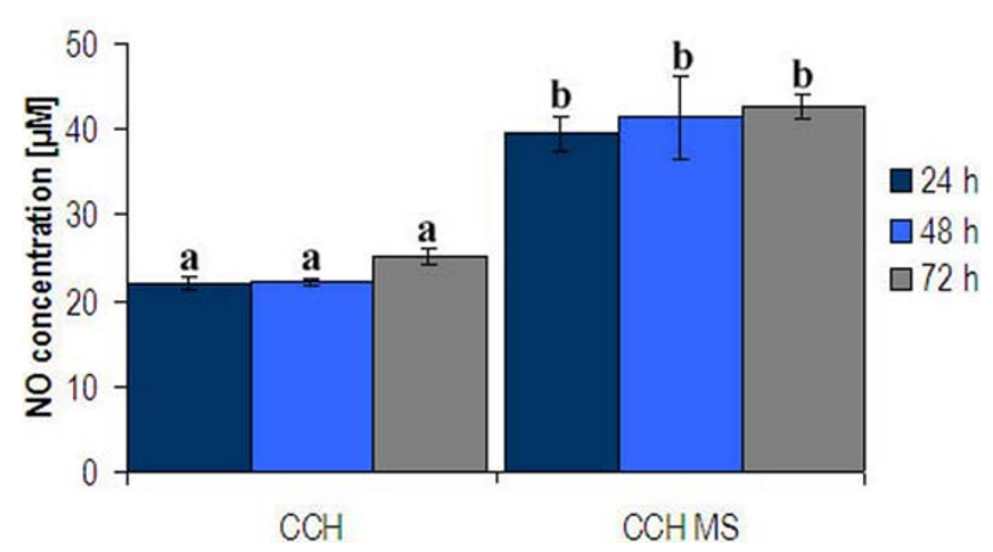

Figure $\mathbf{6}$ Concentration of NO in culture media of $\mathbf{C C H}$ infected with $\mathbf{M}$. synoviae for $\mathbf{2 4}, \mathbf{4 8}$ and $\mathbf{7 2} \mathbf{h}$. NO concentration was determined by the Griess assay. The results are presented as mean concentrations \pm standard error for two independent experiments with three replicates each. Different letters above columns indicate significant differences between NO concentrations (Student $t$-test, $p \leq 0.01$ ).

joints contained antibodies to $\mathrm{CCH}$ and cartilage proteins (Dušanić et al., unpublished observations). This suggests $\mathrm{CCH}$ death and tissue destruction, leading to consequent production of autoantibodies against cartilage and $\mathrm{CCH}$ proteins. Many Mycoplasma species invade non-phagocytic cells and interfere with apoptosis (Table 1) [9-22]. M. synoviae is capable of invading $\mathrm{CCH}$ [8]. The interactions between $\mathrm{CCH}$ and $M$. synoviae are likely to occur via binding of $M$. synoviae hemagglutinin VlhA to $\mathrm{CCH}$ receptors containing Sia $(\alpha$ 2-6) gal and Sia ( $\alpha$ 2-3) gal, and their desialylation with $M$. synoviae neuraminidase $[8,56]$, Dušanić et al. unpublished observations]. Its effect on cell viability has, however, not been reported before this study.

This is the first report of mycoplasma-induced apoptosis in chondrocytes. The XTT proliferation assay was performed on chicken chondrocytes infected with $M$. synoviae and a major decrease in cell respiration was noted, suggesting cell death had occurred (Figure 1). Chondrocyte morphology, evaluated under phase contrast microscope and confocal microscope combined with anti-CD44 receptor and propidium iodide staining additionally indicated cytopathology with apoptotic features in chondrocytes infected with M. synoviae (Figures 2 and 3$)$.

RT-qPCR analysis, performed on 15 genes involved in apoptosis (Table 2, Figure 4), involved NO production in apoptosis induction. The Griess assay confirmed secretion of NO to supernates (Figure 6). NO production is closely linked to chondrocyte apoptosis and cartilage loss in human arthropathies such as osteoarthritis and rheumatoid arthritis [30-33]. Also, NO production was shown to be strongly upregulated in chicken macrophages infected with M. synoviae or in contact with its lipoprotein MSPB [57]. Both endogenously and exogenously produced $\mathrm{NO}$ is capable of inducing chondrocyte apoptosis, but the analysis here was limited to NO produced by chondrocytes as a result of $M$. synoviae infection. As expected, Mapk11 (encoding p38B, the major inducer of NO-linked apoptosis) was upregulated as well, $24 \mathrm{~h}$ and $48 \mathrm{~h}$ after infection. It has been reported that p38 causes upregulation and stimulation of caspase 3 activity, and upregulation of $\mathrm{NF} \kappa \mathrm{B}$ transcription factor $[34,35]$. In our study, upregulation was noticed in genes encoding both caspase 3 and $\mathrm{NF} \kappa \mathrm{B} 1$, as well as in genes encoding other related apoptotic proteins (Figures 4 and 5).

Increased transcription of caspase genes is the most probable explanation for the formation of apoptotic bodies and cell shrinkage in infected $\mathrm{CCH}$ [25]. Although genes encoding endonuclease G, which is released from the mitochondria during apoptosis, and Bak1, a pro-apoptotic mitochondrial protein, were not upregulated, another mitochondrial nuclease, encoded by AIFM1, was strongly upregulated $72 \mathrm{~h}$ after infection, indicating mitochondrial involvement (Figures 4 and 5). Occurrence of Fas receptor mediated apoptosis, which has been reported in chondrocytes [35], was disregarded due to unchanged transcription of both Fas and FASLG during $\mathrm{CCH}$ infection with $M$. synoviae (Additional file 1, Figure S1). Apoptosis inhibitor, encoded by BCL2, was slightly upregulated after $72 \mathrm{~h}$, but so was htrA3, encoding the inhibitor of $\mathrm{Bcl} 2$. The expression of another apoptotic inhibitor, encoded by XIAP, remained unaltered (Additional file 1, Figure S1).

Taken together, our results indicate that $M$. synoviae induces endogenic nitric oxide mediated, caspase 3 and 8 dependent apoptosis in chicken chondrocytes, which involves a loss of mitochondrial function (Figure 5).

5-fluorouracil was used as a positive control of the experiment due to its well established apoptotic effect on other cell lines [58]. Compared to M. synoviae, it 
induced a stronger and faster apoptotic response in $\mathrm{CCH}$ (Figure 4, Additional file 1, Figure S1, Figures 2 and 3 ). The profile of gene expression modulations indicate a Fas receptor mediated, caspase 3 independent cell death involving mitochondrial inactivation. Interestingly, the Jurkat cell line that was used as a positive control of the viability test shows great susceptibility to $M$. synoviae infection (Figure 1).

Although live intracellular M. synoviae were re-cultivated in our previous study 24 and $48 \mathrm{~h}$ after infection, the percentage of $\mathrm{CCH}$ invasion was relatively low $(1.2$ \pm 0.3 for the type strain WVU 1853) [8]. This study demonstrates a high susceptibility to cell death in infected chondrocytes. This suggests that M. synoviae affects $\mathrm{CCH}$ both from the outer side of the membrane, probably in a Fas independent manner, and from its location within the cell. It is also possible that mycoplasmas die in cell culture due to their complex nutritional demands, but their antigens continue to stimulate $\mathrm{CCH}$ and cause stress. An example of macrophage stimulation to produce NO, IL6 and IL1 $\beta$ by $M$. synoviae lipoprotein MSPB has been reported previously [57].

With the exception of caspase 3, patterns of apoptotic gene upregulation were not confirmed on the protein level due to the scarcity of the appropriate specific antibodies to chicken proteins or enzymes involved in apoptotic signal transduction cascades. Even with caspase 3, the antibody used was not specific enough to recognize the cleaved form of the protein (Additional file 2, Figure S2). Still, correlations between demonstrated cytopathologic changes, results of the XTT tests, Griess assay and gene expression data indicate apoptosis and not necrosis as the main mechanism of cell death. As an additional confirmation, $\mathrm{CCH}$ infected with $M$. synoviae were labeled using Annexin V-FITC (AV) and propidium iodide $(\mathrm{PI})$ to discriminate between live $\left(\mathrm{AV}^{-} \mathrm{PI}^{-}\right)$, early apoptotic $\left(\mathrm{AV}^{+} \mathrm{PI}^{-}\right)$, late apoptotic $\left(\mathrm{AV}^{+} \mathrm{PI}^{+}\right)$and primary/ secondary necrotic cells $\left(\mathrm{AV}^{-} \mathrm{PI}^{+}\right)$. The results show an increase in the percentage of cells with phosphatidylserine exposed on the outer membrane layer, to which AV is bound, in the first two days of infection. This was followed by an increase in cells labeled only with PI, indicating secondary necrosis (Additional file 3, Figure S3).

In conclusion, this study provides the first demonstration of mycoplasma-induced apoptosis of chondrocytes. This process may lead to the development of $M$. synoviae-induced infectious synovitis in the chicken, a disease that in many factors resembles human infectious arthritis. It also supports the hypothesis that mycoplasma-induced arthritic conditions in animals might be useful models for understanding the role of mycoplasmas in similar human diseases. Hence, the study may have value outside the immediate interest of avian arthritis.

\section{Additional material}

Additional file 1: Figure S1: Expression of genes for which no significant alterations could be detected after exposure of $\mathrm{CCH}$ to M. synoviae WVU 1853. Exposure agent and time of exposure (in hours) are indicated below columns. Control (CTRL) represents in all graphs non-exposed $\mathrm{CCH}$. Results are given as mean values \pm standard error for three independent cell treatment experiments with three RT-qPCR replicates for each experiment. (file format: EPS).

Additional File 2: Figure S2: Immunodetection of caspase 3 protein in $\mathrm{CCH}$ cell lysates. CCH were infected with M. synoviae WVU 1853 for 24, 48 and 72 h. Cells were then lysed in IP lysis buffer $(10 \mathrm{mM}$ Tris $\mathrm{HCl}$ $\mathrm{pH} 7.4,150 \mathrm{mM} \mathrm{NaCl}, 0.1 \%$ NP-40, $0.002 \mathrm{M}$ EDTA) with $0.1 \%$ protease inhibitor cocktail (Sigma) and kept at $-20^{\circ} \mathrm{C}$. Protein concentration was determined by adding $160 \mu \mathrm{L}$ of Bradford reagent (Bio-Rad) to $40 \mu \mathrm{L}$ of cell lysate samples diluted 1:100 in miliQ water and comparing $A_{595}$ values to those obtained for bovine serum albumin (BSA) solutions with known concentrations. Cell lysates containing $60 \mu \mathrm{g}$ of total proteins were prepared for polyacrilamide gel electrophoresis by adding $2 \mu \mathrm{L}$ of dithiothreitol (DTT; RD Systems) and $5 \mu \mathrm{L}$ of loading buffer (Fermentas) to $18 \mu \mathrm{L}$ of sample. Samples were separated on a $12 \%$ polyacrylamide gel $30 \%$ acrylamide mix, ammonium persulfate, N, N, N', N'tetramethylethylenediamine, Trizma base from Sigma-Aldrich, sodium dodecyl-sulfate from Merck) and transferred onto a polyvinyl-difluoride membrane (Imobilon-P, Millipore) in electroblotting buffer (N-cyclohexyl3-aminopropanesulfonic acid, MetOH from Sigma-Aldrich) by applying $0.8 \mathrm{~mA} / \mathrm{cm}^{2}$ of gel for $45 \mathrm{~min}$. The membrane was blocked overnight in $3 \% \mathrm{BSA}$ at $4^{\circ} \mathrm{C}$ and incubated in rabbit monoclonal antibodies to human caspase 3 or $\alpha / \beta$ tubulin (1:2000 in Tween20 solution in phosphate buffered saline $\mathrm{pH} 7.0$ (Tween-PBS), both from Cell Signaling Technology, USA) for $2 \mathrm{~h}$ at room temperature. Following washing in $0.05 \%$ TweenPBS, horseradish peroxidase-labeled goat anti rabbit lgG (1:5000 in 0.05\% Tween-PBS, Sigma-Aldrich) were used as secondary antibodies. BM chemiluminiscence blotting substrate (Roche) was used for detection on film paper (reagents from Ilford). Note that increased synthesis of caspase 3 is evident, although the antibody failed to recognize $17 \mathrm{kDa}$ fragments of cleaved enzyme.

Additional file 3: Figure S3: Flow cytometry analysis of Annexin VFITC and propidium iodide stained non-infected $\mathrm{CCH}(\mathrm{a}, \mathrm{b}, \mathrm{c}, \mathrm{g})$ and CCH infected with M. synoviae WVU 1853 (d, e, f, g). CCH were infected as described in the Materials and methods section, washed in PBS and scraped using a rubber policeman. Washed cells were resuspended in $100 \mu \mathrm{L} 1 \times$ binding buffer $(10 \times$ stock solution: $0.1 \mathrm{M}$ HEPES pH 7.4, 1.4 M NaCl, $25 \mathrm{mM} \mathrm{CaCl}_{2}$ ) and stained by adding $5 \mu \mathrm{L}$ Anexin V-FITC (BD Pharmingen) and $10 \mu \mathrm{L}$ propidium iodide (PI, $10 \mu \mathrm{g} /$ $\mathrm{mL}$ stock, Sigma-Aldrich). Cells were incubated at room temperature for $15 \mathrm{~min}$, followed by addition of another $400 \mu \mathrm{L}$ of $1 \times$ binding buffer. In order to stain nuclei of live cells, DAPI (final concentration $3 \mu \mathrm{M}$, Invitrogen) was used just before flow cytometric analysis. Single color controls for Annexin V-FITC, PI and DAPI were used to set compensations. Annexin V-FITC was detected in the 536/40 nm channel after excitation with the $488 \mathrm{~nm}$ blue laser $(50 \mathrm{~mW})$. PI was detected in the $675 / 25 \mathrm{~nm}$ after excitation with the $488 \mathrm{~nm}$ blue laser $(50 \mathrm{~mW})$. DAPI was detected in the $455 / 25 \mathrm{~nm}$ channel after excitation with the $405 \mathrm{~nm}$ violet diode laser (100 $\mathrm{mW}$ ). With this set up no compensation was needed. Cells were analyzed on a CyFlow Space (Partec) fitted with a $488 \mathrm{~nm}$ blue laser and violet diode $405 \mathrm{~nm}$ with FlowMax software. DAPI positive and CCH positive (based on FSC/SSC) signals were used for gating. Live cells were defined as $\mathrm{AVPI}^{-}$, early apoptotic as $\mathrm{AV}^{+} \mathrm{PI}^{-}$, late apoptotic as $\mathrm{AV}^{+} \mathrm{PI}^{+}$, and primary/secondary necrotic cells as $\mathrm{AVPI}^{+}$.

List of abbreviations used

NO: nitric oxide; CCH: chicken chondrocytes; XTT: 2, 3-bis-(2-methoxy-4-nitro5-sulfophenyl)-2H-tetrazolium-5-carboxanilide; RT-qPCR: quantitative real-time polymerase chain reaction; 5-FU: 5-fluorouracil; Casp3: gene encoding caspase 3; BCL2: gene encoding B-cell CLL/lymphoma 2 protein (BCl2); Bak1: gene encoding BCl2 antagonist/killer protein 1 (Bak1); FASLG: gene encoding the Fas receptor ligand; tp53: tumor protein 53 gene, encoding p53 protein; 
AIFM1: apoptosis-inducing factor gene, encoding AIFM1 protein; CASP8: gene encoding caspase 8; endog: gene encoding endonuclease G; XIAP: gene encoding the X-linked inhibitor of apoptosis (XIAP); NOS2: gene encoding the inducible nitric oxide synthase (NOS2); NFKB1: gene encoding the nuclear factor of kappa light polypeptide gene enhancer in B-cells 1 (NFkB1); htrA3: gene encoding the HtrA serine peptidase 3; Mapk11: gene encoding the mitogen activated protein kinase 3 (MAPK11 or p38B); GAPDH: gene encoding glyceraldehyde-3-phosphate dehydrogenase (GAPDH); Bax: $\mathrm{BCl} 2-$ associated $\mathrm{X}$ protein; $\mathrm{Bid}$ : $\mathrm{BH} 3$ interacting domain death agonist (truncated form: tBid).

\section{Acknowledgements}

This work was supported by grant 1000-07-310121 from the Ministry of Education and Science of the Republic of Slovenia. The authors would like to thank Dr Nataša Kopitar Jerala (Jožef Stefan Institute, Slovenia) for donating Jurkat cells, Iva Horvat for doing the proliferation assay and Ana Jakopič for technical assistance.

\section{Author details}

${ }^{1}$ University of Ljubljana, Department of Animal Science, Chair for Genetics, Animal Biotechnology and Immunology, Groblje 3, 1230 Domzale, Slovenia. ${ }^{2}$ National Institute of Chemistry Slovenia, L12 Laboratory of Biotechnology, Hajdrihova 19, 1001 Ljubljana, Slovenia.

\section{Authors' contributions}

DD conceived the study, carried out the isolation of $\mathrm{CCH}$, infection of cells, RNA isolation and subsequent gene expression analysis, all microscopy and $\mathrm{NO}$ concentration assays, performed the statistical analysis and drafted the manuscript. DB carried out M. synoviae cultivation and CFU determination and participated in manuscript editing. 10 advised DD on RT-qPCR and participated in manuscript drafting. IC participated in M. synoviae cultivation, determining the number of CFU and performing RT-qPCR. MB participated in performing confocal microscopy and flow cytometry analysis. MN participated in designing the study, drafting the manuscript and coordination between authors. All authors read and approved the final manuscript.

\section{Competing interests}

The authors declare that they have no competing interests.

Received: 21 June 2011 Accepted: 26 January 2012

Published: 26 January 2012

\section{References}

1. Lockaby SB, Hoerr FJ, Lauerman LH, Kleven SH: Pathogenicity of Mycoplasma synoviae in broiler chickens. Vet Pathol 1998, 35:178-190.

2. Lockaby SB, Hoerr FJ, Lauerman LH, Smith BF, Samoylov AM, TolvioKinnucan MA, Kleven SH: Factors associated with virulence of Mycoplasma synoviae. Avian Dis 1999, 43:251-261.

3. Hinz KH, Blome C, Ryll M: Virulence of Mycoplasma strains in experimentally infected broiler chickens. Berl Munch Tierartzl Wochenschr 2003, 116:59-66.

4. Kleven SH: Mycoplasma synoviae infection. In Diseases of Poultry.. 11 edition. Edited by: Saif YM, Barnes HJ, Glisson JR, Fadly AM, McDougald LR, Swayne DE. Ames: lowa State University Press; 2003:756-766.

5. Narat M, Benčina D, Kleven SH, Habe F: The hemagglutination-positive phenotype of Mycoplasma synoviae induces experimental infectious synovitis in chickens more frequently than does the hemagglutinationnegative phenotype. Infect Immun 1998, 66:6004-6009.

6. Kohn DF, Magill LS, Chinookoswong N: Localisation of Mycoplasma pulmonis in cartilage. Infect Immun 1982, 35:730-733.

7. Hill A, Dagnal GJR: Experimental arthritis in rats produced by Mycoplasma arthritidis. J Comp Pathol 1975, 85:45-52.

8. Dušanić D, Berčič RL, Cizelj I, Salmič S, Narat M, Benčina D: Mycoplasma synoviae invades non-phagocytic chicken cells in vitro. Vet Microbiol 2009, 138:114-119.

9. Obara $H$, Harasawa R: Nitric oxide causes anoikis through attenuation of E-cadherin and activation of caspase-3 in human gastric carcinoma AZ521 cells infected with Mycoplasma hyorhinis. J Vet Med Sci 2010, 72:869-874.
10. Van der Merwe J, Prysliak T, Perez-Casal J: Invasion of bovine peripheralblood mononuclear cells and erythrocytes by Mycoplasma bovis . Infect Immun 2010, 78:4570-4578.

11. Vanden Bush TJ, Rosenbusch RF: Mycoplasma bovis induces apoptosis of bovine lymphocytes. FEMS Immunol Med Microbiol 2002, 32:97-103.

12. Gerlic M, Horowitz J, Horowitz S: Mycoplasma fermentans inhibits tumor necrosis factor a-induced apoptosis in the myelomonocytic U937 cell line. Cell Death Differ 2004, 11:1204-1212.

13. Zhang S, Tsai S, Wu TT, Li B, Shih JW, Lo SC: Mycoplasma fermentans infection promotes immortalization of human peripheral blood mononuclear cells in culture. Blood 2004, 104:4252-4259.

14. Zhang S, Lo SC: Effect of Mycoplasmas on apoptosis of 32D cells is species.dependent. Curr Microbiol 2007, 54:388-395.

15. Kawahito $Y$, Ichinose $S$, Sano H, Tsubouchi Y, Kohno M, Yoshikawa T, Tokunaga D, Hojo T, Harasawa R, Nakano T, Matsuda K: Mycoplasma fermentans glycolipid-antigen as a pathogen in rheumatoid arthritis. Biochem Biophys Res Commun 2008, 369:561-566.

16. Hunt ME, Brown DR: Role of sialidase in Mycoplasma alligatoris-induced pulmonary fibroblast apoptosis. Vet Microbiol 2007, 121:73-82.

17. Hopfe M, Henrich B: OppA, the ecto-ATPase of Mycoplasma hominis induces ATP release and cell death in HeLa cells. BMC Microbiol 2008, 8:55.

18. Zeng Y, Wu Y, Deng Z, You X, Zhu C, Yu M, Wan Y: Apoptosis induced by lipid-associated membrane proteins from Mycoplasma penetrans is mediated by nuclear factor KB activation in mouse macrophage. Can J Microbiol 2008, 54:150-158.

19. Shcheblyakov DV, Logunov DY, Zubkova OV, Shmarov MM, Rakovskaya IV, Naroditskii BS, Gintsburg AL, Gudkov AV: Mycoplasma infection with M. arginini results in NF-KB constitutive activation and inhibition of apoptosis in cells expressing Toll-like receptors TLR2/6. Mol Gen Mikrobiol Virusol 2008, 23:163-167.

20. Logunov DY, Scheblyakov DV, Zubkova OV, Shmarov MM, Rakovskaya IV, Gurova KV, Tararova ND, Burdelya LG, Naroditsky BS, Ginzburg AL, Gudkov AV: Mycoplasma infection supresses p53, activates NF-kB and cooperates with oncogenic Ras in rodent fibroblast transformation. Oncogene 2008, 27:4521-4531.

21. Wu Y, Qiu H, Zeng Y, You X, Deng Z, Yu M, Zhu C: Mycoplasma genitalium lipoproteins induce human monocytic cell expression of proinflammatory cytokines and apoptosis by activating nuclear factor KB. Mediators Inflamm 2008, 2008:195427.

22. Feng SH, Tsai S, Rodriguez J, Lo SC: Mycoplasmal infections prevent apoptosis and induce malignant transformation of interleukin-3dependent 32D hematopoietic cells. Mol Cel Biol 1999, , 19: 7995-8002.

23. Muzio M, Stockwell BR, Stennicke HR, Salvesen GS, Dixit VM: An induced proximity model for caspase-8 activation. J Biol Chem 1998, 273:2926-2930.

24. Lüthi AU, Martin SJ: The CASBAH: a searchable database of caspase substrates. Cell Death Differ 2007, 14:641-650.

25. Taylor RC, Cullen SP, Martin SJ: Apoptosis: controlled demolition at the cellular level. Nat Rev Mol Cell Biol 2008, 9:231-241.

26. Arnoult D, Gaume B, Karbowski M, Sharpe J, Cecconi F, Youle RJ: Mitochondrial release of AIF and EndoG requires caspase activation downstream of Bax/Bak-mediated permeabilization. EMBO J 2003, 22:4385-4399.

27. Bossy-Wetzel E, Newmeyer DD, Green DR: Mitochondrial cytochrome c release in apoptosis occurs upstream of DEVD-specific caspase activation and independently of mitochondrial transmembrane depolarization. EMBO J 1998, 17:37-49.

28. Hsu YT, Wolter KG, Youle RJ: Cytosol-to-membrane redistribution of Bax and BCl-X during apoptosis. Proc Natl Acad Sci USA 1997, 94:3668-3672.

29. Blanco FJ, Ochs RL, Schwartz H, Lotz M: Chondrocyte apoptosis induced by nitric oxide. Am J Pathol 1995, 146:75-85.

30. Schuerwegh AJ, Dombrecht EJ, Stevens WJ, Van Offel JF, Kockx MM, Bridts CH, De Clerck LS: Synovial fluid and peripheral blood immune complexes of patients with rheumatoid arthritis induce apoptosis in cytokine-activated chondrocytes. Rheumatol Int 2007, 27:901-909.

31. Lotz M: The role of nitric oxide in articular cartilage damage. Rheum Dis Clin North Am 1999, 25:269-282.

32. Murel GA, Doland MM, Jang D, Szabo C, Warren RF, Hannafin JA: Nitric oxide: an important articular free radical. J Bone Joint Surg Am 1996, 78:265-274. 
33. Pelletier JP, Fernandes JC, Jovanovic DV, Reboul P, Martel-Pelletier J: Chondrocyte apoptosis in experimental osteoarthritis is mediated by MEK $1 / 2$ and p38 pathways: role of cyclooxygenase- 2 and inducible nitric oxide synthase. J Rheumatol 2001, 28:2509-2519.

34. Kim SJ, Ju JW, Oh CD, Yoon YM, Song WK, Kim JH, Yoo YJ, Bang OS, Kang SS, Chun JS: ERK-1/2 and p38 kinase oppositely regulate nitric oxide-induced apoptosis of chondrocytes in association with p53, caspase-3 and differentiation status. J Biol Chem 2002, 277:1332-1339.

35. Wei L, Sun XJ, Wang Z, Chen Q: CD95-induced osteoarthritic chondrocyte apoptosis and necrosis: dependency on p38 mitogen-activated protein kinase. Arthritis Res Ther 2006, 8:R37.

36. Rodwell AW, Whitcomb RF: Methods for direct and indirect measurement of mycoplasma growth Methods in Mycoplasmology. Edited by: Razin S, Tully JG. Academic Press; 1983:1:185-196.

37. Fuji K, Fuji Y, Hubscher S, Tanaka Y: CD44 is the physiological trigger of Fas up-regulation on rheumatoid synovial cells. J Immunol 2001, 167:1198-1203.

38. National Center for Biotechnology Information/Primer-BLAST. [http:// www.ncbi.nlm.nih.gov/tools/primer-blast/index.cgi?LINK_LOC=BlastHome].

39. Bliss T, Dohms JE, Emara MG, Keeler CL Jr: Gene expression profiling of avian macrophage activation. Vet Immunol Immunopathol 2005, 105:289-299.

40. Toegel S, Huang W, Piana C, Unger FM, Wirth M, Goldring MB, Gabor F, Viernstein $\mathrm{H}$ : Selection of reliable reference genes for qPCR studies on chondroprotective action. BMC Mol Biol 2007, 8:13.

41. Pfaffl MW: A new mathematical model for relative quantification in realtime RT-PCR. Nucleic acids Res 2001, 29:e45.

42. Willems $E$, Leyns L, Vandesompele J: Standardization of real-time PCR gene expression data from independent biological replicates. Anal Biochem 2008, 379:127-129.

43. Kim HA, Song YW: Apoptotic chondrocyte death in rheumatoid arthritis. Arthritis Rheum 1999, 42:1528-1537.

44. Röhner E, Detert J, Kolar P, Hocke A, N'Guessan P, Matziolis G, Kanitz V, Bernimoulin JP, Kielbassa A, Burmester GR, Buttgereit F, Pischon N: Induced apoptosis of chondrocytes by Porphyromonas gingivalis as a possible pathway for cartilage loss in rheumatoid arthritis. Calcif Tissue Int 2010, 87:333-340.

45. Wegner N, Lundbreg K, Kinloch A, Ficher B, Malmström V, Feldman M Venables PJ: Autoimmunity to specific citrullinated proteins gives the first clues to the etiology of rheumatoid arthritis. Immunol Rev 2010, 233:34-54.

46. Van Der Heijden IM, Wilbrink B, Tchetverikov I, Schrijver A, Schouls LM, Hazenberg MP, Breedveld FC, Tak PP: Presence of bacterial DNA and bacterial peptydoglycans in joints of patients with rheumatoid arthritis and other arthritidies. Arthritis Rheum 2000, 43:593-598.

47. Silverman G: Regulatory natural autoantibodies to apoptotic cells: pallbearers and protectors. Arthritis Rheum 2011, 63:597-602.

48. Hashimoto S, Ochs RL, Komiya S, Lotz M: Linkage of chondrocyte apoptosis and cartilage degradation in human osteoarthritis. Arthritis Rheum 1998, 41:1632-1638.

49. Haier J, Nasralla M, Franco AR, Nicolson GL: Detection of mycoplasmal infections in blood of patients with rheumatoid arthritis. Rheumatology 1999, 38:504-509.

50. Schaeverbeke $T$, Renaudin $H$, Clerc M, Lequen L, Vernhes JP, De Barbeyrac B, Bannwarth B, Bèbèar C, Dehais J: Systematic detection of mycoplasmas by culture and polimerase chain reaction (PCR) procedures in 209 synovial fluid samples. Br J Rheumatol 1997, 36:310-314.

51. Horowitz S, Evinson B, Borer A, Horowitz J: Mycoplasma fermentans in rheumatoid arthritis and other inflammatory arthritidies. J Rheumatol 2000, 12:2747-2753.

52. Gilroy CB, Keat A, Taylor-Robinson D: The prevalence of Mycoplasma fermentans in patients with inflammatory arthritidies. Rheumatology 2001, 40:1355-1358.

53. Ramírez AS, Rosas A, Hernández-Beriain JA, Orengo JC, Saavedra P, de la Fe C, Fernández A, Poveda JB: Relationship between rheumatoid arthritis and Mycoplasma pneumoniae: a case-control study. Rheumatology 2005, 44:912-914.

54. Johnson SM, Bruckner F, Collins D: Distribution of Mycoplasma pneumoniae and Mycoplasma salivarium in the synovial fluids of arthritis patients. J Clin Microbiol 2007, 45:953-957.
55. Kerr KM, Olson O: Pathology of chickens inoculated experimentally or contact-infected with Mycoplasma synoviae. Avian Dis 1970, 14:290-320.

56. Berčič RL, Cizelj I, Dušanić D, Narat M, Zorman-Rojs O, Dovč P, Benčina D: Neuraminidase of Mycoplasma synoviae desialylates heavy chain of the chicken immunoglobulin $\mathrm{G}$ and glycoproteins of chicken tracheal mucus. Avian Pathol 2011, 40:299-308.

57. Lavrič M, Benčina D, Kothlow S, Kaspers B, Narat M: Mycoplasma synoviae lipoprotein MSPB, the N-terminal part of VlhA haemagglutinin, induces secretion of nitric oxide, IL- 6 and IN1beta in chicken macrophages. Vet Microbiol 2007, 121:278-287.

58. Backus HHJ, Dukers DF, van Groeningen CJ, Vos W, Bloemena E, Wouters D, van Riel JMGH, Smid K, Giaccone G, Pinedo HM, Peters GJ: 5-fluorouracil induces Fas upregulation associated with apoptosis in liver metastases of colorectal cancer patients. Ann Oncol 2001, 12:209-216.

doi:10.1186/1297-9716-43-7

Cite this article as: Dusanic et al:: Mycoplasma synoviae induces upregulation of apoptotic genes, secretion of nitric oxide and appearance of an apoptotic phenotype in infected chicken chondrocytes. Veterinary Research 2012 43:7.

\section{Submit your next manuscript to BioMed Central and take full advantage of:}

- Convenient online submission

- Thorough peer review

- No space constraints or color figure charges

- Immediate publication on acceptance

- Inclusion in PubMed, CAS, Scopus and Google Scholar

- Research which is freely available for redistribution

Submit your manuscript at www.biomedcentral.com/submit
C Biomed Central 